\title{
Two New Terpenoids from Talaromyces purpurogenus
}

\author{
Wenjing Wang, Xiao Wan, Junjun Liu ${ }^{\circledR}$, Jianping Wang, Hucheng Zhu, Chunmei Chen * and \\ Yonghui Zhang * (iD \\ Hubei Key Laboratory of Natural Medicinal Chemistry and Resource Evaluation, Tongji Medical College, \\ Huazhong University of Science and Technology, Wuhan 430030, China; wangwj0122@163.com (W.W.); \\ marina.wanx@gmail.com (X.W.); junjun.liu@hust.edu.cn (J.L.); jpwang1001@163.com (J.W.); \\ zhuhucheng@hust.edu.cn (H.Z.) \\ * Correspondence: chenchunmei@hust.edu.cn (C.C.); zhangyh@mails.tjmu.edu.cn (Y.Z.); \\ Tel.: +86-27-8369-2892 (C.C.); +86-27-8369-2892 (Y.Z.)
}

Received: 30 March 2018; Accepted: 27 April 2018; Published: 2 May 2018

\begin{abstract}
A new sesquiterpenoid 9,10-diolhinokiic acid (1) and a new diterpenoid roussoellol C (2), together with 4 known compounds, were isolated from the extracts of laboratory cultures of marine-derived fungus Talaromyces purpurogenus. 9,10-diolhinokiic acid is the first thujopsene-type sesquiterpenoid containing a 9,10-diol moiety, and roussoellol C possesses a novel tetracyclic fusicoccane framework with an unexpected hydroxyl at C-4. These new structures were confirmed by spectroscopic data, chemical method, NMR data calculations and electronic circular dichroism (ECD) calculations. The selected compounds were evaluated for cytotoxicities against five human cancer cell lines, including SW480, HL-60, A549, MCF-7, and SMMC-7721 and the IC $_{50}$ values of compound 2 against MCF-7 and 3 against HL-60 cells were 6.5 and $7.9 \mu \mathrm{M}$, respectively.
\end{abstract}

Keywords: sesquiterpenoid; diterpenoid; Talaromyces purpurogenus; NMR data calculations; ECD calculations; cytotoxicities

\section{Introduction}

Over the past forty years, more than $60 \%$ small molecule new drugs have been directly or indirectly derived from natural product source, which demonstrates that natural products continue to play a significant role in drug discovery and development process [1]. Fungi-derived natural products are rich sources of medicines due to their diverse chemical structures and bioactivities. For example, lovastatin, penicillin, echinocandin B, and cyclosporine A have been clinically used as effective medicines, illustrating the significance of fungi-derived metabolites in drug discovery [2].

The fungus Talaromyces purpurogenus, previously known as Penicillium purpurogenum [3], is widely distributed in terrestrial plants, soil, and marine habitats, and has been reported to produce various secondary metabolites such as meroterpenoids [4,5], polyketides [6-10], lipopeptides [10], and sterols [11]. Meanwhile, the impressive structurally diverse metabolites from this fungus exhibit extensive bioactivities including anti-inflammatory [11], anti-influenza virus [7], insecticidal [4], antitumor [9], and antifungal activities [8]. In our screening of extracts of several fungi for their cytotoxic activities, EtOAc extract of T. purpurogenus, isolated from a mud sample, showed significant cytotoxic activity in vitro. A chemical investigation of the fungus T. purpurogenus resulted in the isolation of two new secondary metabolites 9,10-diolhinokiic acid (1) and roussoellol C (2), and four known compounds including dankasterone (3) [12,13], cyclotryprostatin E (4) [14], 6-methoxyspirotryprostatin B (5) [15], and (3S,12aS)-3-methyl-2,3,6,7,12,12ahexahydropyrazino $\left[1^{\prime}, 2^{\prime}: 1,6\right]$ pyrido[3,4-b]indole-1,4-dion (6) (Figure 1) [16]. Details of isolation, structural elucidation, and cytotoxic activities are presented here. 

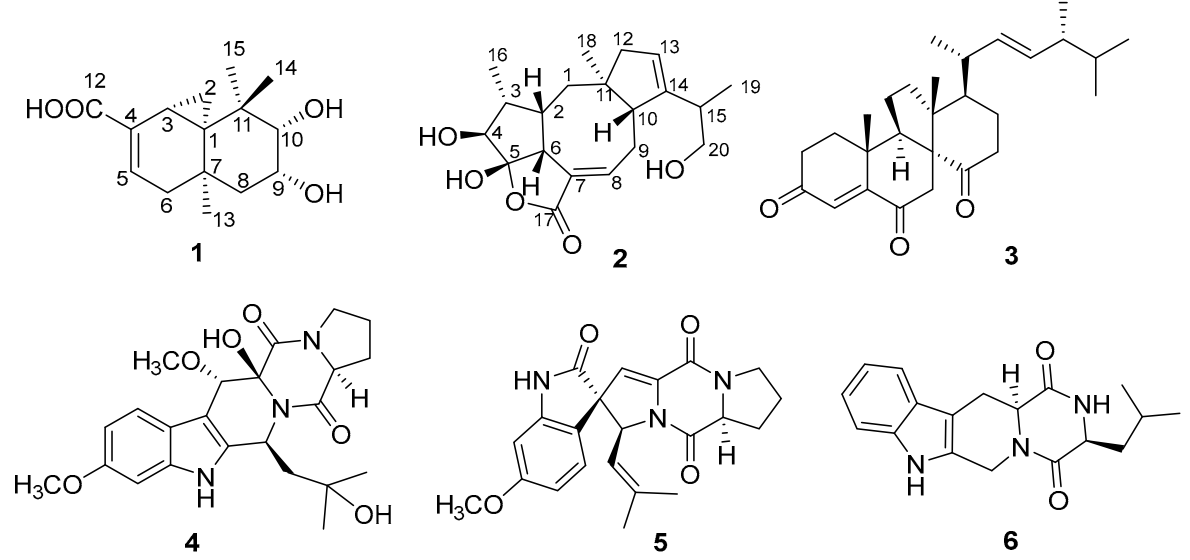

Figure 1. The structures of compounds 1-6.

\section{Results and Discussion}

\subsection{Chemical Identification of Isolated Terpenoids}

Compound 1 was isolated as pale yellow oil. The molecular formula of $\mathrm{C}_{15} \mathrm{H}_{22} \mathrm{O}_{4}$, containing 5 degrees of unsaturation, was deduced from its HRESIMS spectrum $\left(m / z 265.1450[\mathrm{M}-\mathrm{H}]^{-}\right.$; calcd. for $\mathrm{C}_{15} \mathrm{H}_{21} \mathrm{O}_{4}, 265.1440$ ). The IR spectrum gave a hydroxyl absorption band at $3432 \mathrm{~cm}^{-1}$ and unsaturated carboxyl and double bond absorbances at 1696 and $1647 \mathrm{~cm}^{-1}$, respectively. The ${ }^{1} \mathrm{H}$ NMR data (Table 1) of 1 showed the existence of one olefinic proton at $\delta_{\mathrm{H}} 6.56(1 \mathrm{H}, \mathrm{dd}, J=7.0,1.8 \mathrm{~Hz})$; two oxygenated protons at $\delta_{\mathrm{H}} 3.23(1 \mathrm{H}, \mathrm{d}, J=3.8 \mathrm{~Hz})$ and $4.03(1 \mathrm{H}$, ddd, $J=3.8,3.7,3.1 \mathrm{~Hz})$; three methyl signals at $\delta_{\mathrm{H}} 1.44,1.31$, and 0.78 . The ${ }^{13} \mathrm{C}$ NMR and DEPT data (Table 1 ) showed only 13 carbon resonances, comprising one olefinic carbon $\left[\delta_{\mathrm{C}} 133.7(\mathrm{C}-5)\right]$, three methyls $\left[\delta_{\mathrm{C}} 30.6(\mathrm{C}-13), 25.9(\mathrm{C}-14)\right.$, and $23.5(\mathrm{C}-15)]$, three methylenes $\left[\delta_{\mathrm{C}} 11.3(\mathrm{C}-2), 42.8(\mathrm{C}-6)\right.$, and $\left.41.5(\mathrm{C}-8)\right]$, three methines including two oxygenated carbons $\left[\delta_{\mathrm{C}} 17.9(\mathrm{C}-3), 72.8(\mathrm{C}-9)\right.$, and $\left.78.6(\mathrm{C}-10)\right]$, as well as three quaternary carbons $\left[\delta_{\mathrm{C}} 35.7(\mathrm{C}-1), 31.9(\mathrm{C}-7)\right.$, and $\left.39.9(\mathrm{C}-11)\right]$. The missing carbons in the ${ }^{13} \mathrm{C}$ NMR including a carboxyl $\left(\delta_{\mathrm{C}} 171.2\right)$ and an olefinic carbon $\left(\delta_{\mathrm{C}} 134.3\right)$ were revealed by cross-peaks in the HMBC spectrum. These data indicated compound 1 to be a sesquiterpenoid.

Exhaustive analyses of the 2D NMR spectra of 1 revealed some similarity to (+)-thujopsene [17], a sesquiterpenoid derivative isolated from the liverwort Marchantia polymorpha. However, two oxygenated methines $\left(\delta_{\mathrm{H}} 4.03, \delta_{\mathrm{C}} 72.8\right.$ and $\left.\delta_{\mathrm{H}} 3.23, \delta_{\mathrm{C}} 78.6\right)$ of 1 replaced the methylenes of $(+)$-thujopsene and one methyl was oxidized to a carboxyl $\left(\delta_{C} 171.2\right)$ group. The presence of a 9,10-diol moiety was demonstrated by the ${ }^{1} \mathrm{H}-{ }^{1} \mathrm{H}$ COSY cross-peak of $\mathrm{H}-9$ and $\mathrm{H}-10$, and HMBC correlations from H-9 to C-7 and C-11 and from H-10 to C-8 and C-11. The carboxyl was located at C-4, which was substantiated by the HMBC cross-peaks from H-3 and H-5 to C-12 (Figure 2). Therefore, the planar structure of 1 was identified as a 9,10-diolhinokiic acid [18]. In the NOESY experiment (Figure 2), the correlations of $\mathrm{H}-2 / \mathrm{Me}-15$ and $\mathrm{H}-2 / \mathrm{Me}-13$ suggested that these groups were co-facial and assigned as $\alpha$-oriented, while, the interactions of $\mathrm{H}-3 / \mathrm{Me}-14$ and $\mathrm{Me}-14 / \mathrm{H}-10$ indicated that they were on the opposite face of the ring system and $\beta$-oriented. The hydroxyls at C-9 and C-10 were on the same side according to the coupling constant between $\mathrm{H}-9$ and $\mathrm{H}-10(\mathrm{~J}=3.8 \mathrm{~Hz})$. Thus, the relative configuration of 1 was determined. The absolute stereochemistry of the 9,10-diol moiety in $\mathbf{1}$ was verified by observing the induced electronic circular dichroism (IECD) spectrum after the addition of dimolybdenum tetraacetate in anhydrous DMSO [19,20]. The obvious negative Cotton effect at $310 \mathrm{~nm}$ in the IECD spectrum (Figure 3) permitted the $9 R, 10 S$ configuration assignment of 1 . Combining with the relative configuration, the absolute stereochemistry of $\mathbf{1}$ was elucidated as $1 R, 3 R, 7 R, 9 R, 10 S$ (Figure 1). 

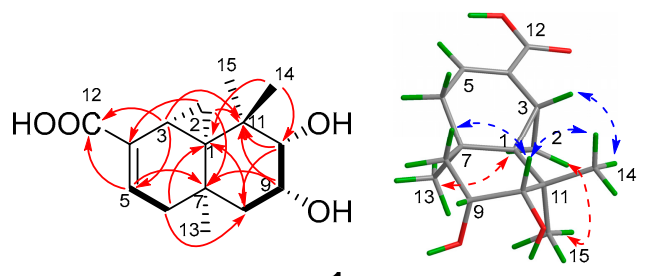

- COSY $\frown \mathrm{HMBC}$
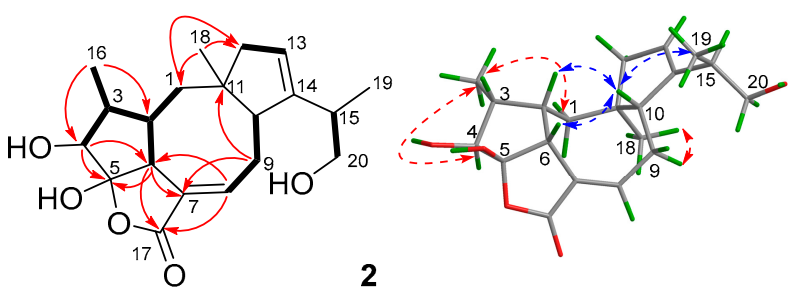

Figure 2. Key 2D correlations of compounds 1 and 2.

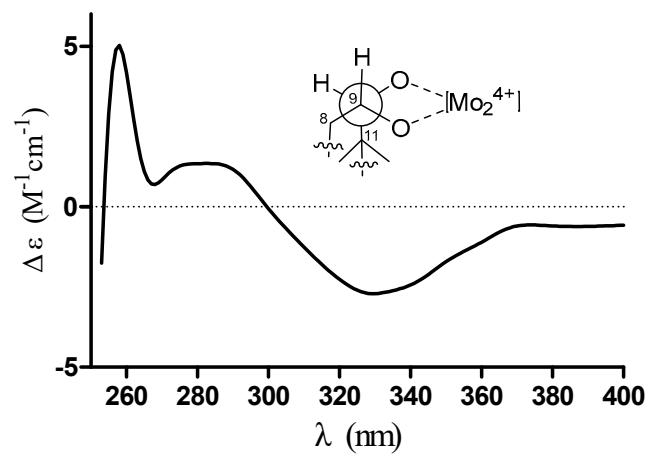

Figure 3. Conformation of the $\mathrm{Mo}_{2}{ }^{4+}$ complex of compound 1 and its IECD spectrum in DMSO.

Compound 2 was isolated as colorless oil that gave a $[\mathrm{M}+\mathrm{Na}]^{+}$ion peak in the HRESIMS spectrum at $m / z 371.1839 \Delta \mathrm{m}$ (calcd. for $\mathrm{C}_{20} \mathrm{H}_{28} \mathrm{O}_{5} \mathrm{Na}$, 371.1834) appropriate for a molecular formula of $\mathrm{C}_{20} \mathrm{H}_{28} \mathrm{O}_{5}$, corresponding to 7 degrees of unsaturation. The IR spectrum showed a hydroxyl $\left(3430 \mathrm{~cm}^{-1}\right)$ and an ester or lactone carbonyl $\left(1742 \mathrm{~cm}^{-1}\right)$. The ${ }^{1} \mathrm{H}$ NMR data (Table 1$)$ of 2 revealed two olefinic protons at $\delta_{\mathrm{H}} 7.04(1 \mathrm{H}, \mathrm{m})$ and $5.31(1 \mathrm{H}, \mathrm{s})$; three oxygenated protons at $\delta_{\mathrm{H}} 3.81(1 \mathrm{H}, \mathrm{d}, J=$ $4.4 \mathrm{~Hz}), 3.66(1 \mathrm{H}, \mathrm{dd}, J=10.6,5.3 \mathrm{~Hz})$, and $3.37(1 \mathrm{H}, \mathrm{dd}, J=10.6,7.9 \mathrm{~Hz})$; three methyl signals at $\delta_{\mathrm{H}} 0.84$ $(3 \mathrm{H}, \mathrm{s}), 0.93(3 \mathrm{H}, \mathrm{d}, J=7.4 \mathrm{~Hz})$, and $1.04(3 \mathrm{H}, \mathrm{d}, J=6.8 \mathrm{~Hz})$. The ${ }^{13} \mathrm{C}$ NMR and DEPT spectra (Table 1$)$ displayed resonances for 20 carbon signals categorized as one carbonyl carbon $\left[\delta_{\mathrm{C}} 173.0\right.$ (C-17)], four olefinic carbons $\left[\delta_{\mathrm{C}} 130.5(\mathrm{C}-7), 141.6(\mathrm{C}-8), 122.1(\mathrm{C}-13)\right.$, and $\left.148.4(\mathrm{C}-14)\right]$, one sp ${ }^{3}$ quaternary carbon [ $\left.\delta_{\mathrm{C}} 46.9(\mathrm{C}-11)\right]$, one hemiketal carbon $\left[\delta_{\mathrm{C}} 114.1(\mathrm{C}-1)\right]$, six methines including one oxygenated carbon [ $\delta_{\mathrm{C}} 41.2(\mathrm{C}-2), 40.8(\mathrm{C}-3), 80.0(\mathrm{C}-4), 52.8$ (C-6), 47.9 (C-10), and 36.7 (C-15)], four methylenes including one oxygenated carbon $\left[\delta_{\mathrm{C}} 37.6(\mathrm{C}-1), 26.8(\mathrm{C}-9), 45.5(\mathrm{C}-12)\right.$, and $\left.67.0(\mathrm{C}-20)\right]$, and three methyls $\left[\delta_{\mathrm{C}}\right.$ 11.0 (C-16), 24.9 (C-18), and 17.7 (C-19)]. Consideration of these data and analyses of the ${ }^{1} \mathrm{H}-{ }^{1} \mathrm{H}$ COSY and HMBC spectra (Figure 2) of 2 suggested existence of tetracyclic fusicoccane framework which was similar with that of roussoellol B [21]. Further analyses of the 2D NMR spectra indicated that the methylene at C-4 in roussoellos B was oxygenated $\left(\delta_{C} 80.0\right)$, which was confirmed by ${ }^{1} \mathrm{H}-{ }^{1} \mathrm{H}$ COSY cross-peak of H-3 and H-4 and the HBMC correlations from H-4 to C-3, C-5, C-6, and C-16. In addition, the $\Delta^{10,14}$-double bond in roussoello $B$ shifted to $C-13$ and $C-14$ which was evidenced by the HBMC correlations from H-13 to C-10, C-11, and C-12. Moreover, HMBC correlations from H-15 and $\mathrm{H}-19$ to the oxygenated methylene carbon at $\delta_{\mathrm{C}} 67.0$ (C-20) indicated the presence of a hydroxymethyl functionality. Hence, the planar structure of $\mathbf{2}$ was established as shown.

In the NOESY experiment (Figure 2), the NOESY correlations of $\mathrm{H}-2 / \mathrm{H}-10, \mathrm{H}-6 / \mathrm{H}-10$, and $\mathrm{H}-10 / \mathrm{Me}-19$ indicated the $\beta$-orientation for these protons. Meanwhile, correlations of $\mathrm{H}-1 / \mathrm{Me}-16$, Me-16/H-4, and Me-18/H-9 suggested that H-4, Me-16, and Me-18 were on the opposite side and $\alpha$-oriented. Even though the NOESY correlation of H-10/Me-19 were observed, but the configuration of $\mathrm{C}-15$ could not be determined by the NOESY experiment due to the freely rotation of the bond between $\mathrm{C}-14$ and $\mathrm{C}-15$. In order to determine the relative configuration of $5-\mathrm{OH}$, the theoretical calculation 
of ${ }^{13} \mathrm{C}$ NMR chemical shifts of epimers $\mathbf{2 a}$ and $\mathbf{2} \mathbf{b}$ (Figure 4) were performed to semiempirical PM3 quantum mechanical geometry optimizations using Gaussian09 at the B3LYP/6-31G* level [22]. The experimental shifts were plotted against the calculated shifts, and least-squares fit lines was confirmed. The calculated shifts for $\mathbf{2 a}$ and $\mathbf{2} \mathbf{b}$ were corrected by the slope and intercept to get the corrected ${ }^{13} \mathrm{C}$ shifts (Table 1), and the differences between the corrected and experimental ${ }^{13} \mathrm{C}$ NMR chemical shifts were analyzed [23,24]. The result showed that the correlation coefficient $R^{2}$ of $2 \mathbf{a}$ (0.9966) was higher than that of $\mathbf{2 b}$ (0.9926) (Figures S21 and S22). Meanwhile, the MAE (mean absolute error) and $\mathrm{MD}$ (maximum deviation) of $2 \mathrm{a}(\mathrm{MAE}=2.28, \mathrm{MD}=6.5$ ) were obviously lower than that of $\mathbf{2} \mathbf{b}(\mathrm{MAE}=2.74, \mathrm{MD}=14.3)$, suggesting that $\mathbf{2} \mathbf{a}$ was more consistent with the experimental values (Figure 4). What's more, all of the reported fusicoccanes or ophiobolins with $5 / 8 / 5 / 5$ ring system possess a cis-fused A/D ring [21,25-28], and the 5-OH of $\mathbf{2}$ was finally assigned a $\beta$-orientation as $\mathbf{2 a}$.

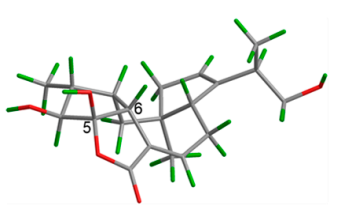

2a

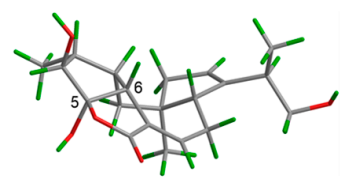

$2 b$

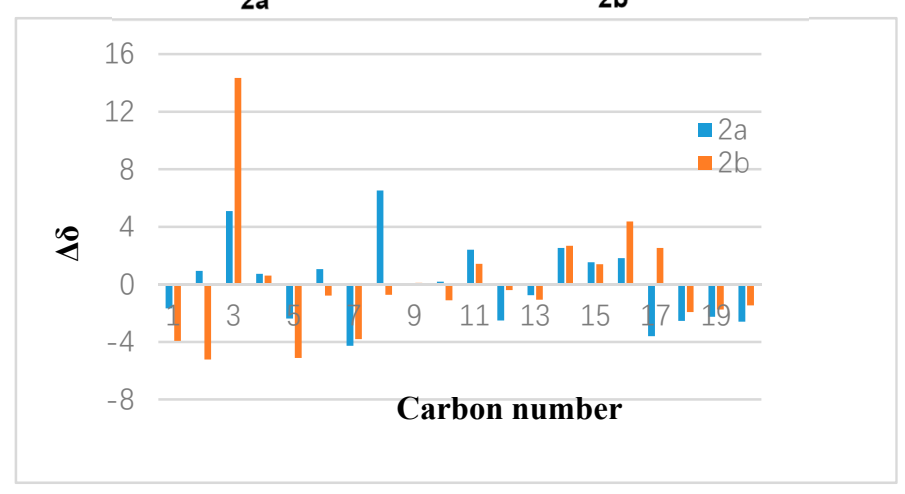

Figure 4. Structures and differences in ppm between calculated and experimental ${ }^{13} \mathrm{C}$ NMR shifts for $2 \mathbf{a}$ and $\mathbf{2 b}$.

To determine the absolute configuration of compound 2, the electronic circular dichroism (ECD) calculation was performed. The experimental and simulated spectra generated by BALLOON $[29,30]$ were performed to semiempirical PM3 quantum mechanical geometry optimizations using the Gaussian 09 program (Figures S2 and S3, Supplementary Materials) [31]. The ECD spectrum of each conformer was calculated using the TDDFT methodology at B3LYP/6-311++G(d,p)//B3LYP/6-31G(d) level. Comparison of the experimental and calculated spectra of 2 showed more agreement (Figure 5) for the 2a configuration. The experimental ECD is consistent with the calculated ECD of 2 (Figure 5), indicating a $(2 S, 3 R, 4 S, 5 S, 6 R, 10 R, 11 S)$-configuration. Therefore, the structure of $\mathbf{2}$, namely, roussoellol $\mathrm{C}$, was deduced as shown.

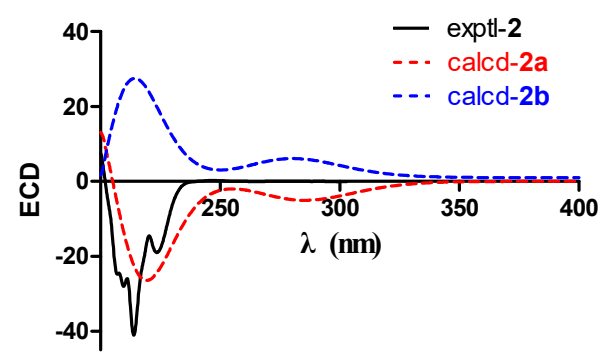

Figure 5. Experimental and calculated ECD spectra of 2. 
Table 1. ${ }^{1} \mathrm{H}(400 \mathrm{MHz})$ and ${ }^{13} \mathrm{C}$ NMR (100 MHz) Data for Compound $\mathbf{1}$ and $\mathbf{2}\left(\mathrm{CD}_{3} \mathrm{OD}\right)$ and DFT Calculation of ${ }^{13} \mathrm{C}$ NMR for $\mathbf{2 a}$ and $\mathbf{2 b}$.

\begin{tabular}{|c|c|c|c|c|c|c|c|c|}
\hline \multirow{2}{*}{ Position } & \multicolumn{2}{|l|}{1} & \multicolumn{2}{|l|}{2} & \multicolumn{2}{|c|}{$2 a$} & \multicolumn{2}{|c|}{$2 b$} \\
\hline & $\delta_{\mathrm{H}}(J$ in $\mathrm{Hz})$ & $\delta_{\mathrm{C}}$ & $\delta_{\mathrm{H}}(J$ in $\mathrm{Hz})$ & $\delta_{\mathrm{C}}$ & $\delta_{\mathrm{C}}$ (calcd.) & $\delta_{\mathrm{C}}($ cor) & $\delta_{\mathrm{C}}$ (calcd.) & $\delta_{\mathrm{C}}$ (cor) \\
\hline 1 & - & 35.7 & $1.60, \mathrm{~d}, 13.01 .40, \mathrm{dd}, 14.6,13.0$ & 37.6 & 39.2 & 35.9 & 36.2 & 33.7 \\
\hline 2 & $\begin{array}{c}0.85, \mathrm{dd}, 9.1,5.0 \\
0.76, \mathrm{~d}, 5.1\end{array}$ & 11.3 & $2.70, \mathrm{~m}$ & 41.2 & 45.7 & 42.1 & 38.6 & 36.0 \\
\hline 3 & $2.11, \mathrm{dd}, 9.0,5.1$ & 17.9 & $2.45, \mathrm{~m}$ & 40.8 & 49.6 & 45.9 & 58.7 & 55.1 \\
\hline 4 & - & 134.3 & $3.81, d, 4.4$ & 80.0 & 86.0 & 80.7 & 85.4 & 80.6 \\
\hline 5 & $6.56, d, 4.6$ & 133.7 & - & 114.1 & 118.4 & 111.7 & 115.2 & 109.0 \\
\hline 6 & $\begin{array}{l}1.88, \mathrm{dd}, 18.3,2.6 \\
1.78, \mathrm{dd}, 18.3,7.0\end{array}$ & 42.8 & 3.42, br d, 9.4 & 52.8 & 57.9 & 53.8 & 55.4 & 52.0 \\
\hline 7 & - & 31.9 & - & 130.5 & 133.5 & 126.2 & 133.7 & 126.7 \\
\hline 8 & $\begin{array}{l}1.57, \mathrm{dd}, 14.4,3.1 \\
1.50, \mathrm{dd}, 14.4,3.7\end{array}$ & 41.5 & $7.04, \mathrm{~m}$ & 141.6 & 156.4 & 148.1 & 148.6 & 140.9 \\
\hline 9 & 4.03, ddd, $3.8,3.7,3.1$ & 72.8 & 2.65, overlap $2.36, \mathrm{~m}$ & 28.6 & 31.4 & 28.5 & 31.0 & 28.7 \\
\hline 10 & $3.23, \mathrm{~d}, 3.8$ & 78.6 & $3.19, \mathrm{dd}, 13.6,2.8$ & 47.9 & 51.9 & 48.1 & 50.0 & 46.8 \\
\hline 11 & - & 39.9 & - & 46.9 & 53.2 & 49.3 & 51.6 & 48.3 \\
\hline 12 & - & 171.2 & $2.28, \mathrm{dd}, 15.1,4.21 .76, \mathrm{dd}, 15.1,2.6$ & 45.5 & 46.6 & 43.0 & 48.2 & 45.9 \\
\hline 13 & $1.44, \mathrm{~s}$ & 30.6 & 5.31 , br s & 122.1 & 128.4 & 121.3 & 127.8 & 121.0 \\
\hline 14 & $0.78, \mathrm{~s}$ & 25.9 & - & 148.4 & 159.3 & 150.9 & 159.3 & 151.1 \\
\hline 15 & $1.31, \mathrm{~s}$ & 23.5 & $2.22, \mathrm{ddq}, 7.9,5.3,7.4$ & 36.7 & 41.6 & 38.2 & 40.8 & 38.1 \\
\hline 16 & & & $0.93, d, 7.4$ & 11.0 & 15.0 & 12.8 & 17.0 & 15.4 \\
\hline 17 & & & - & 173.0 & 178.6 & 169.4 & 184.9 & 175.5 \\
\hline 18 & & & $0.84, \mathrm{~s}$ & 24.9 & 25.0 & 22.4 & 25.0 & 23.0 \\
\hline 19 & & & $1.04, \mathrm{~d}, 6.8$ & 17.7 & 17.7 & 15.4 & 17.5 & 15.8 \\
\hline 20 & & & $3.66, \mathrm{dd}, 10.6,5.33 .37, \mathrm{dd}, 10.6,7.9$ & 67.0 & 68.9 & 64.4 & 69.6 & 65.5 \\
\hline
\end{tabular}




\subsection{Cytotoxic Activities of Selected Compounds}

The growth inhibitory effects of the selected compounds (1-3) against human colonic carcinoma cell line (SW480), human promyelocytic leukemia cells (HL-60), human non-small-cell lung cancer cells (A549), breast adenocarcinoma cell line (MCF-7), and human hepatocellular carcinoma cell line (SMMC-7721) were assayed by using MTT method [32], with adriamycin as the positive control. Compounds 1-3 exhibited moderate antiproliferative activities against these cells with $\mathrm{IC}_{50}$ values ranging from 6.5 to $35.7 \mu \mathrm{M}$ (Table 2). Normally, cytotoxic natural products display better activities against HL-60 than any other cancer cell lines because HL-60 cells are much sensitive in the assay. However, it is interesting that compound 2 showed significant selectivity toward MCF-7 cells with an $\mathrm{IC}_{50}$ value of $6.5 \mu \mathrm{M}$ but with an $\mathrm{IC}_{50}$ value of $10.9 \mu \mathrm{M}$ against HL-60. Although an $\mathrm{IC}_{50}$ value of $6.5 \mu \mathrm{M}$ does not indicate strong potency, the selectivity of 2 against MCF-7 still makes it a promising lead compound for further studies.

Table 2. Cytotoxicities against Tumor Cells for $1-3\left(\mathrm{IC}_{50}, \mu \mathrm{M}\right)$.

\begin{tabular}{ccccc}
\hline & $\mathbf{1}$ & $\mathbf{2}$ & $\mathbf{3}$ & Adriamycin \\
\hline SW480 & $>40$ & 23.6 & 14.2 & 1.2 \\
HL-60 & 12.6 & 10.9 & 7.9 & 0.05 \\
A549 & 35.7 & 25.8 & 21.3 & 0.10 \\
MCF-7 & $>40$ & 6.5 & 23.8 & 0.80 \\
SMMC-7721 & $>40$ & $>40$ & $>40$ & 0.2 \\
\hline
\end{tabular}

\section{Materials and Methods}

\subsection{General Experimental Procedures}

Optical rotations were measured on a Rudolph Autopol IV automatic polarimeter with a $0.7 \mathrm{~mL}$ cell (Rudolph Research Analytical, Hackettstown, NJ, USA). UV spectra were recorded with a PerkinElmer Lambda 35 spectrophotometer (PerkinElmer, Inc., Fremont, CA, USA). IR spectra were measured on a Bruker Vertex 70 FT-IR spectrophotometer (Bruker, Karlsruhe, Germany). ECD data were obtained with a JASCO-810 instrument (JASCO Co., Ltd., Tokyo, Japan). HRESIMS data were recorded on a Thermo Fisher LTQ XL LC/MS (Thermo Fisher, Palo Alto, CA, USA). 1D and 2D NMR spectra were measured with a Bruker AM-400 NMR spectrometer at $25^{\circ} \mathrm{C}$ (Bruker, Karlsruhe, Germany), the NOESY mixing time was 100 ms. Compounds were purified by an Agilent 1220 HPLC system semi-preparative HPLC (Agilent Technologies Inc., Santa Clara, CA, USA) equipped with a UV detector (Agilent Technologies Inc.). Column chromatography was performed on silica gel (100-200 and 200-300 mesh, Qingdao Marine Chemical Inc., Qingdao, China), Sephadex LH-20

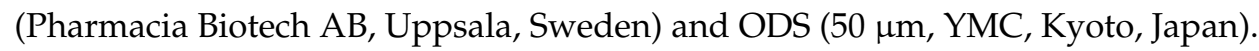

\subsection{Fungal Material}

The fungus PP-414 was isolated from a mud sample collected on the coastal beach in Qinghuangdao County, Hebei Province, China. The mud sample (5 g) was suspended in $50 \mathrm{~mL}$ sterile water with a concentration at $10^{-1} \mathrm{~g} / \mathrm{mL}$ and then every $0.5 \mathrm{~mL}$ mutterlauge was respectively diluted to $10^{-2}, 10^{-3}, 10^{-4} \mathrm{~g} / \mathrm{mL}$ with sterile water. Each sample was coated individually on potato dextrose agar (PDA) medium contained chloramphenicol, and incubated at $28{ }^{\circ} \mathrm{C}$ to get single colonies by routine microbiological methods. The internal transcribed spacer (ITS) region was amplified by PCR using primers ITS1 (5'-TCCGTAGGTGAACCTGCGG-3') and ITS4 (5'-TCCTCCGCTTATTGATATGC-3'), then submitted to GenBank and identified as Talaromyces purpurogenus by ITS sequence homology $(99 \%$ similarity with Talaromyces purpurogenus strain Q2, accession no. KX432212.1 (max score 974, query cover $96 \%, e$ value 0.0 )) and physiological characteristics with accession no. MH120320. The voucher 
sample, PP-414, has been preserved in the culture collection center of Tongji Medical College, Huazhong University of Science and Technology (Wuhan, China).

\subsection{Fermentation and Isolation}

The fungus PP-414 was incubated on potato dextrose agar (PDA) at $28{ }^{\circ} \mathrm{C}$ for 7 days, the agar cultures were cut into small pieces (approximately $0.5 \times 0.5 \times 0.5 \mathrm{~cm}^{3}$ ) and then inoculated into $100 \times 1 \mathrm{~L}$ Erlenmeyer flasks which containing $250 \mathrm{~g}$ rice and $250 \mathrm{~mL}$ distilled water. After incubating at $28{ }^{\circ} \mathrm{C}$ for 28 days, the solid rice medium was distilled with $\mathrm{CH}_{3} \mathrm{CH}_{2} \mathrm{OH}$ and then extracted three times with EtOAc. The EtOAc extract $(80 \mathrm{~g})$ was chromatographed on silica gel chromatography column (CC, 80-120 mesh) eluting with petroleum ether /EtOAc (100:0-0:1, $v / v)$ to afford five fractions (Fr. A-Fr. E). Fr. C (4.5 g) was further separated by Sephadex LH-20 $\left(\mathrm{CH}_{2} \mathrm{Cl}_{2} / \mathrm{MeOH} 1: 1\right)$ and silica gel CC (200-300 mesh) eluting with $\mathrm{CH}_{2} \mathrm{Cl}_{2} / \mathrm{MeOH}(200: 1-20: 1, v / v)$ to obtain four fractions (C1-C5), Fr. C2 was further purified by semi-preparative HPLC $\left(\mathrm{MeCN}-\mathrm{H}_{2} \mathrm{O}, 85: 15, v / v\right)$ to yield $3(9.0 \mathrm{mg}$, $\left.t_{\mathrm{R}}=52.5 \mathrm{~min}\right)$. Fr. C3 was further purified by semi-preparative HPLC $\left(\mathrm{MeCN}-\mathrm{H}_{2} \mathrm{O}, 45: 55, v / v\right)$ to obtain $6\left(6.0 \mathrm{mg}, t_{\mathrm{R}}=35.2 \mathrm{~min}\right)$. Fr. C4 was further separated by Sephadex LH-20 (MeOH) and semi-preparative HPLC $\left(\mathrm{MeOH}-\mathrm{H}_{2} \mathrm{O}, 65: 35, v / v\right)$ to yield $4\left(4.5 \mathrm{mg}, t_{\mathrm{R}}=20.0 \mathrm{~min}\right)$ and $5(5.0 \mathrm{mg}$, $\left.t_{\mathrm{R}}=46.0 \mathrm{~min}\right)$.

Fr. D (8.5 g) was further separated by reversed-phase MPLC $\left(\mathrm{MeOH} / \mathrm{H}_{2} \mathrm{O}, 10: 90-100: 0\right)$ to obtain seven fractions (D1-D7), Fr. D6 was purified by Sephadex LH-20 $\left(\mathrm{CH}_{2} \mathrm{Cl}_{2} / \mathrm{MeOH} 1: 1\right)$ and silica gel CC (200-300 mesh) eluting with $\mathrm{CH}_{2} \mathrm{Cl}_{2} / \mathrm{MeOH}(200: 1-10: 1, v / v)$ to obtain four fractions (D6.1-D6.4), Fr. D6.3 was further purified by semi-preparative HPLC $\left(\mathrm{MeOH}-\mathrm{H}_{2} \mathrm{O}, 65: 35, v / v\right)$ to yield $\mathbf{1}(2.5 \mathrm{mg}$, $\left.t_{\mathrm{R}}=16.0 \mathrm{~min}\right)$. Fr. D6.4 was further separated by semi-preparative HPLC $\left(\mathrm{MeOH}-\mathrm{H}_{2} \mathrm{O}, 55: 45, v / v\right)$ to yield $2\left(1.1 \mathrm{mg}, t_{\mathrm{R}}=27.5 \mathrm{~min}\right)$.

Compound 1: pale yellow oil $(\mathrm{MeOH}),[\alpha]_{\mathrm{D}}^{25}+43.0(c 0.1, \mathrm{MeOH}) ; \mathrm{UV}(\mathrm{MeOH}) \lambda_{\max }(\log \varepsilon) 203$ (3.71), 235 (3.51) nm; CD (MeOH) $\lambda_{\max }(\Delta \varepsilon) 203$ (-1.37), 233 (2.17), 263 (0.54), 282 (0.72), 335 (-0.13) nm; IR $v_{\max } 3432,2923,1696,1647,1382,1246,1062 \mathrm{~cm}^{-1} ;{ }^{1} \mathrm{H}$ and ${ }^{13} \mathrm{C}$ NMR data, see Table 1 ; HRESIMS $\mathrm{m} / \mathrm{z}$ $265.1450[\mathrm{M}-\mathrm{H}]^{-}$(calcd. for $\mathrm{C}_{15} \mathrm{H}_{21} \mathrm{O}_{4}, 265.1440$ ).

Compound 2: colorless oil (MeOH), $[\alpha]_{\mathrm{D}}^{25}-4.0\left(c\right.$ 0.05, MeOH); UV (MeOH) $\lambda_{\max }(\log \varepsilon) 202$ (3.87), 212 (3.81), $225(3.84) \mathrm{nm} ; \mathrm{CD}(\mathrm{MeOH}) \lambda_{\max }(\Delta \varepsilon) 212(-7.28), 232(-2.44), 243(-3.34) \mathrm{nm} ; \mathrm{IR} v_{\max } 3430$, 2928, 1742, 1631, 1384, 1218, $1027 \mathrm{~cm}^{-1} ;{ }^{1} \mathrm{H}$ and ${ }^{13} \mathrm{C}$ NMR data, see Table 1 ; HRESIMS $\mathrm{m} / z$ 371.1839 $[\mathrm{M}+\mathrm{Na}]^{+}$(calcd. for $\mathrm{C}_{20} \mathrm{H}_{28} \mathrm{O}_{5} \mathrm{Na}, 371.1834$ ).

\subsection{NMR Calculation}

The ${ }^{13} \mathrm{C}$ NMR chemical shifts of each conformer were calculated at the B3LYP/6-311++G(d,p)// B3LYP/6-31G(d) level by the IEFPCM solvation model implemented using Gaussian 09 program with $\mathrm{MeOH}$ as solvent, which were then combined using Boltzmann weighting according to their population contributions. The detailed methods were the same as previously described [33].

\subsection{ECD Calculation}

The electronic circular dichroism (ECD) spectra of each conformer were calculated by the TDDFT methodology with $\mathrm{MeOH}$ as solvent. The detailed methods were the same as previously described [32] The ECD spectra of each conformer were simulated using a Gaussian function with a bandwidth $\sigma$ of $0.4 \mathrm{eV}$. The spectra were combined after Boltzmann weighting according to their population contributions and UV correction was applied.

\subsection{Cytotoxicity against Cancer Cell Lines}

Cytotoxicity of the selected compounds against the five cancer cell lines (SW480, HL-60, A549, MCF-7, and SMMC-7721) was evaluated by the MTT method with adriamycin as positive control. All cells were cultured in RPMI.1640 medium contained 10\% fetal bovine serum, $2 \mathrm{mM}$ 
L-glutamine, $100 \mathrm{U} / \mathrm{mL}$ penicillin, and $100 \mu \mathrm{g} / \mathrm{mL}$ streptomycin at $37^{\circ} \mathrm{C}$ in a humidified atmosphere with $5 \% \mathrm{CO}_{2}$. Tumor cells were seeded in 96-well microtiter plates at 5000 cells/wel, and the test compounds at concentrations ranging from 1.56 to $50 \mu \mathrm{M}$ were added to the wells $12 \mathrm{~h}$ later. After incubation for $48 \mathrm{~h}$, the metabolic conversion of $20 \mu \mathrm{L}$ of MTT $(5 \mathrm{mg} / \mathrm{mL})$ 3-(4,5-dimethylthiazol-2-yl)-2,5-diphenyltetrazolium bromide was added and the incubation was continued for $4 \mathrm{~h}$ at $37^{\circ} \mathrm{C}$. The medium was exchanged with the medium containing $100 \mu \mathrm{L}$ triplex solution of $10 \% \mathrm{SDS}, 5 \%$ isopropyl alcohol and $12 \mathrm{mM} \mathrm{HCl}$ and then cultured $12-20 \mathrm{~h}$ at $37^{\circ} \mathrm{C}$. The results were obtained using a microplate spectrophotometer plate reader at $570 \mathrm{~nm}$ and the value of inhibition was calculated by formula: \% inhibition $=\left[\left(\mathrm{OD}_{\text {control }}-\mathrm{OD}_{\text {treated }}\right) / \mathrm{OD}_{\text {control }}\right] \times 100 \%$. Selected compounds were tested at five concentrations (50, 25, 12.5, 6.25, 3.12 and $1.56 \mu \mathrm{M})$ in $100 \%$ DMSO with a final concentration of DMSO was $0.5 \%(v / v)$ in each well. The $\mathrm{IC}_{50}$ values were calculated by the means \pm SEM calculating by GraphPad Prism 5 .

\section{Conclusions}

In conclusion, we have reported six metabolites, including two new structures from the culture extract of T. purpurogenus. Among them, 9,10-diolhinokiic acid (1) is the first reported thujopsene-type sesquiterpenoid containing a 9,10-diol moiety and roussoellol C (2) possesses a novel tetracyclic fusicoccane diterpenoid with an unexpected hydroxyl at C-4. This study further enriched the structure diversity of secondary metabolites of this species. Additionally, compound 2 showed significant selectivity aginst MF-7 with $\mathrm{IC}_{50}$ values of $6.5 \mu \mathrm{M}$, which makes it a promising lead compound for further studies.

Supplementary Materials: The following are available online at http:/ /www.mdpi.com/1660-3397/16/5/150/s1, HR-ESI-MS, IR, UV and NMR spectra of new compounds $\mathbf{1}$ and 2, as well as computational data for compound 2.

Author Contributions: W.W. conducted the main experiments, data analyzes, and wrote the manuscript, X.W. and J.L. were responsible for the NMR and ECD calculations, J.W. conducted the fermentation of fungi, H.Z. analyzed the spectroscopic data, C.C. and Y.Z. designed the experiments and commented on the manuscript.

Funding: This work was financially supported by the Program for Changjiang Scholars of Ministry of Education of the People's Republic of China (No. T2016088); National natural Science Foundation for Distinguished Young Scholars (No. 81725021); Innovative Research Groups of the National Natural Science Foundation of China (81721005); the Academic Frontier Youth Team of HUST; the Integrated Innovative Team for Major Human Diseases Program of Tongji Medical College (HUST).

Acknowledgments: We thank the Analytical and Testing Center at Huazhong University of Science and Technology for assistance in testing of ECD, UV and IR analyses. We thank Chong Dai and Ying Tang for assistance in isolated experiment.

Conflicts of Interest: The authors declare no conflict of iterest.

\section{References}

1. Newman, D.J.; Cragg, G.M. Natural products as sources of new drugs from 1981 to 2014. J. Nat. Prod. 2016, 79, 629-661. [CrossRef] [PubMed]

2. Evidente, A.; Kornienko, A.; Cimmino, A.; Andolfi, A.; Lefrance, F.; Mathieu, V.; Kiss, R. Fungal metabolites with anticancer activity. Nat. Prod. Rep. 2014, 31, 617-627. [CrossRef] [PubMed]

3. Samson, R.A.; Yilmaz, N.; Houbraken, J.; Spierenburg, H.; Seifert, K.A.; Peterson, S.W.; Varga, J.; Frisvad, J.C. Phylogeny and nomenclature of the genus talaromyces and taxa accommodated in penicillium subgenus biverticillium. Stud. Mycol. 2011, 70, 159-183. [CrossRef] [PubMed]

4. Centko, R.M.; Williams, D.E.; Patrick, B.O.; Akhtar, Y.; Garcia Chavez, M.A.; Wang, Y.A.; Isman, M.B.; de Silva, E.D.; Andersen, R.J. Dhilirolides E-N, meroterpenoids produced in culture by the fungus Penicillium purpurogenum collected in Sri Lanka: Structure elucidation, stable isotope feeding studies, and insecticidal activity. J. Org. Chem. 2014, 79, 3327-3335. [CrossRef] [PubMed]

5. Silva, E.D.; Williams, D.E.; Jayanetti, D.R.; Centko, R.M.; Patrick, B.O.; Wijesundera, R.L.; Andersen, R.J. Dhilirolides A-D, meroterpenoids produced in culture by the fruit-infecting fungus Penicillium purpurogenum collected in Sri Lanka. Org. Lett. 2011, 13, 1174-1177. [CrossRef] [PubMed] 
6. Sun, J.; Zhu, Z.X.; Song, Y.L.; Ren, Y.; Dong, D.; Zheng, J.; Liu, T.; Zhao, Y.F.; Tu, P.F.; Li, J. Anti-neuroinflammatory constituents from the fungus Penicillium purpurogenum MHZ 111. Nat. Prod. Res. 2017, 31, 562-567. [CrossRef] [PubMed]

7. Wang, H.; Wang, Y.; Wang, W.; Fu, P.; Liu, P.; Zhu, W. Anti-influenza virus polyketides from the acid-tolerant fungus Penicillium purpurogenum JS03-21. J. Nat. Prod. 2011, 74, 2014-2018. [CrossRef] [PubMed]

8. Li, H.; Wei, J.; Pan, S.Y.; Gao, J.M.; Tian, J.M. Antifungal, phytotoxic and toxic metabolites produced by Penicillium purpurogenum. Nat. Prod. Res. 2014, 28, 2358-2361. [CrossRef] [PubMed]

9. Xia, M.W.; Cui, C.B.; Li, C.W.; Wu, C.J.; Peng, J.X.; Li, D.H. Rare chromones from a fungal mutant of the marine-derived Penicillium purpurogenum G59. Mar. Drugs 2015, 13, 5219-5236. [CrossRef] [PubMed]

10. Wu, C.J.; Li, C.W.; Cui, C.B. Seven new and two known lipopeptides as well as five known polyketides: The activated production of silent metabolites in a marine-derived fungus by chemical mutagenesis strategy using diethyl sulphate. Mar. Drugs 2014, 12, 1815-1838. [CrossRef] [PubMed]

11. Xue, J.; Wu, P.; Xu, L.; Wei, X. Penicillitone, a potent in vitro anti-inflammatory and cytotoxic rearranged sterol with an unusual tetracycle core produced by Penicillium purpurogenum. Org. Lett. 2014, 16, 1518-1521. [CrossRef] [PubMed]

12. Amagata, T.; Doi, M.; Tohgo, M.; Minoura, K.; Numata, A. Dankasterone, a new class of cytotoxic steroids produced by a Gymnascella species from a marine sponge. Chem. Commun. 1999, 30, 1321-1322. [CrossRef]

13. Amagata, T.; Tanaka, M.; Yamada, T.; Doi, M.; Minoura, K.; Ohishi, H.; Yamori, T.; Numata, A. Variation in cytostatic constituents of a sponge-derived gymnascella dankaliensis by manipulating the carbon source. J. Nat. Prod. 2007, 70, 1731-1740. [CrossRef] [PubMed]

14. He, F.; Sun, Y.L.; Liu, K.S.; Zhang, X.Y.; Qian, P.Y.; Wang, Y.F.; Qi, S.H. Indole alkaloids from marine-derived fungus Aspergillus sydowii SCSIO 00305. J. Antibiot. 2012, 65, 109-111. [CrossRef] [PubMed]

15. Zhang, M.; Wang, W.L.; Fang, Y.C.; Zhu, T.J.; Gu, Q.Q.; Zhu, W.M. Cytotoxic alkaloids and antibiotic nordammarane triterpenoids from the marine-derived fungus Aspergillus sydowi. J. Nat. Prod. 2008, 71, 985-989. [CrossRef] [PubMed]

16. Wu, G.; Liu, J.; Bi, L.; Zhao, M.; Wang, C.; Baudy-Floc'h, M.; Ju, J.; Peng, S. Toward breast cancer resistance protein (BCRP) inhibitors: Design, synthesis of a series of new simplified fumitremorgin $C$ analogues. Tetrahedron 2007, 63, 5510-5528. [CrossRef]

17. Matsuo, A.; Nakayama, N.; Nakayama, M. Enantiomeric type sesquiterpenoids of the liverwort Marchantia polymorpha. Phytochemistry 1985, 24,777-781. [CrossRef]

18. Norin, T.; Jakobsen, H.J.; Larsen, E.H.; Forsén, S.; Meisingseth, E. The chemistry of the natural order Cupressales. 49. The configuration of thujopsene. Acta Chem. Scand. 1963, 17, 738-748. [CrossRef]

19. Górecki, M.; Jabłońska, E.; Kruszewska, A.; Suszczyńska, A.; Urbańczyklipkowska, Z.; Gerards, M.; Morzycki, J.W.; Szczepek, W.J.; Frelek, J. Practical method for the absolute configuration assignment of tert/tert 1,2-diols using their complexes with $\mathrm{Mo}_{2}(\mathrm{OAc})_{4}$. J. Org. Chem. 2007, 72, 2906-2916. [CrossRef] [PubMed]

20. Wang, W.J.; Li, D.Y.; Li, Y.C.; Hua, H.M.; Ma, E.L.; Li, Z.L. Caryophyllene sesquiterpenes from the marine-derived fungus Ascotricha sp. ZJ-M-5 by the one strain-many compounds strategy. J. Nat. Prod. 2014, 77, 1367-1371. [CrossRef] [PubMed]

21. Takekawa, H.; Tanaka, K.; Fukushi, E.; Matsuo, K.; Nehira, T.; Hashimoto, M. Roussoellols A and B, tetracyclic fusicoccanes from Roussoella hysterioides. J. Nat. Prod. 2013, 76, 1047-1051. [CrossRef] [PubMed]

22. White, K.N.; Amagata, T.; Oliver, A.G.; Tenney, K.; Wenzel, P.J.; Crews, P. Structure revision of spiroleucettadine, a sponge alkaloid with a bicyclic core meager in H-atoms. J. Org. Chem. 2009, 73, 8719-8722. [CrossRef] [PubMed]

23. Rychnovsky, S.D. Predicting NMR spectra by computational methods: Structure revision of hexacyclinol. Org. Lett. 2006, 8, 2895-2898. [CrossRef] [PubMed]

24. Zhan, G.; Zhou, J.; Liu, J.; Huang, J.; Zhang, H.; Liu, R.; Yao, G. Acetylcholinesterase inhibitory alkaloids from the whole plants of Zephyranthes carinata. J. Nat. Prod. 2017, 80, 2462-2471. [CrossRef] [PubMed]

25. Wang, Q.X.; Bao, L.; Yang, X.L.; Liu, D.L.; Guo, H.; Dai, H.Q.; Song, F.H.; Zhang, L.X.; Guo, L.D.; Li, S.J. Ophiobolins P-T, five new cytotoxic and antibacterial sesterterpenes from the endolichenic fungus Ulocladium sp. Fitoterapia 2013, 90, 220-227. [CrossRef] [PubMed] 
26. Wei, H.; Itoh, T.; Kinoshita, M.; Nakai, Y.; Kurotaki, M.; Kobayashi, M. Cytotoxic sesterterpenes, 6-epi-ophiobolin G and 6-epi-ophiobolin N, from marine derived fungus Emericella variecolor GF10. Tetrahedron 2004, 60, 6015-6019. [CrossRef]

27. Liu, H.B.; Edrada-Ebel, R.A.; Ebel, R.; Wang, Y.; Schulz, B.; Draeger, S.; Müller, W.E.G.; Wray, V.; Lin, W.H.; Proksch, P. Ophiobolin sesterterpenoids and pyrrolidine alkaloids from the sponge-derived fungus Aspergillus ustus. Helv. Chim. Acta 2011, 94, 623-631. [CrossRef]

28. Zhu, T.; Lu, Z.; Fan, J.; Wang, L.; Zhu, G.; Wang, Y.; Li, X.; Hong, K.; Piyachaturawat, P.; Chairoungdua, A. Ophiobolins from the mangrove fungus Aspergillus ustus. J. Nat. Prod. 2018, 81, 2-9. [CrossRef] [PubMed]

29. Vainio, M.J.; Johnson, M.S. Generating conformer ensembles using a multiobjective genetic algorithm. J. Chem. Inf. Model. 2007, 47, 2462-2474. [CrossRef] [PubMed]

30. Puranen, J.S.; Vainio, M.J.; Johnson, M.S. Accurate conformation-dependent molecular electrostatic potentials for high-throughput in silico drug discovery. J. Comput. Chem. 2010, 31, 1722-1732. [CrossRef] [PubMed]

31. Frisch, M.J.; Trucks, G.W.; Schlegel, H.B.; Scuseria, G.E.; Robb, M.A.; Cheeseman, J.R.; Scalmani, G.; Barone, V.; Mennucci, B.; Petersson, G.A.; et al. Gaussian 09, Revision D.01, Gaussian, Inc.: Wallingford, CT, USA, 2009.

32. Qiao, Y.; Xu, Q.; Hu, Z.; Li, X.N.; Xiang, M.; Liu, J.; Huang, J.; Zhu, H.; Wang, J.; Luo, Z.; et al. Diterpenoids of the cassane type from Caesalpinia decapetala. J. Nat. Prod. 2016, 79, 3134-3142. [CrossRef] [PubMed]

33. Zhan, G.; Liu, J.; Zhou, J.; Sun, B.; Aisa, H.A.; Yao, G. Amaryllidaceae alkaloids with new framework types from Zephyranthes candida as potent acetylcholinesterase inhibitors. Eur. J. Med. Chem. 2017, 127, 771-780. [CrossRef] [PubMed]

(C) 2018 by the authors. Licensee MDPI, Basel, Switzerland. This article is an open access article distributed under the terms and conditions of the Creative Commons Attribution (CC BY) license (http:/ / creativecommons.org/licenses/by/4.0/). 